\title{
Comparing dairy farm milk yield and components, somatic cell score, and reproductive performance among United States regions using summer to winter ratios
}

\author{
Jenna M. Guinn, ${ }^{1}$ D. T. Nolan, ${ }^{1} \odot$ P. D. Krawczel, ${ }^{2} \odot$ C. S. Petersson-Wolfe, ${ }^{3} \odot$ G. M. Pighetti, ${ }^{2} \odot$ A. E. Stone,${ }^{1,4} \oplus$ \\ S. H. Ward, ${ }^{4,5}{ }^{\circ}$ J. M. Bewley, ${ }^{6} \odot$ and Joao H. C. Costa ${ }^{1 *}$ () \\ ${ }^{1}$ Department of Animal and Food Sciences, University of Kentucky, Lexington 40506 \\ ${ }^{2}$ Department of Animal Science, University of Tennessee, Knoxville 37996 \\ ${ }^{3}$ Department of Dairy Science, Virginia Polytechnic Institute and State University, Blacksburg 24061 \\ ${ }^{4}$ Department of Animal and Dairy Science, Mississippi State University, Starkville 39759 \\ ${ }^{5}$ Department of Animal Science, North Carolina State University, Raleigh 27607 \\ ${ }^{6}$ Alltech, Nicholasville, KY 40356
}

\section{ABSTRACT}

Heat stress abatement is a challenge for dairy producers in the United States, especially in the southern states. Thus, managing heat stress is critical to maintain dairy cow performance in the summer. The ability to employ a metric to measure heat stress and evaluate abatement strategies may benefit dairy producers by providing meaningful feedback on the effectiveness of current and future management strategies with the goal of improving heat stress management. Therefore, this study aimed to explore the use of the summer to winter performance ratio metric to quantify and compare farm performance variables among regions of the United States. Monthly performance data recorded by the Dairy Herd Improvement Association from 2007 to 2016, for all US Dairy Herd Improvement Association herds processing records through Dairy Records Management Systems (Raleigh, NC), were obtained. Season dates were based on the astronomical definition of the Northern Hemisphere with summer as June 21 to September 21 and winter as December 21 to March 19. States were grouped into regions based on climate zone classification. Performance records included a total of 16,573 herds [Northeast $(\mathrm{n}=7,955)$, Midwest ( $\mathrm{n}$ $=6,555)$, Northern Plains $(\mathrm{n}=305)$, Southeast $(\mathrm{n}=$ $1,370)$, and Southern Plains $(\mathrm{n}=388)$ regions]. Herd test day performance variables energy-corrected milk, somatic cell score, milk fat and protein percentage, conception rate, heat detection rate, and pregnancy rate in summer and winter were used to calculate summer to winter ratios for each region. The MIXED procedure of SAS 9.4 (SAS Institute Inc., Cary, NC) was used to

Received December 14, 2018.

Accepted August 20, 2019.

*Corresponding author: costa@uky.edu compare test day performance variables. The effects of year, mean days in milk, mean 150-d milk, mean herd size, and number of milkings per day were included as covariates in the models. Dairy cattle performance in all climate regions was negatively affected by summer heat stress, but some regions greater than others. A difference was also observed among regions when comparing summer to winter ratios for each performance parameter. This indicates that summer performance varies by climate region identified by the summer to winter ratio and demonstrates usefulness of the metric to monitor degree of heat stress based on performance. Key words: benchmark, thermoregulation, management, dairy cattle

\section{INTRODUCTION}

The United States includes several diverse climate regions ranging from subtropical to temperate, which influences the risk of heat stress in dairy cattle differently. Ambient temperature and humidity play the most important roles in contributing to heat stress, especially in high-producing dairy cows (Berman, 2005). Dairy cattle respond to heat stress through changes in respiration rate, sweating, panting, milk production, and reproductive performance (Polsky and von Keyserlingk, 2017), resulting in performance changes during summer months. Differing temperature and humidity for dairy farms in varying climates highlights the need for assessing the effects of heat stress by region.

Temperature and humidity are applied to the temperature-humidity index (THI) equation as a tool to measure environmental stress (Hammami et al., 2013) with changes in performance beginning at a THI of 68 (Zimbelman et al., 2009). The THI is inversely related to milk production (Bohmanova et al., 2007; Dikmen and Hansen, 2009) and overall performance (West, 2003). 
The THI describes general environmental conditions and may not accurately represent the microclimate surrounding each cow in housing, and does not account for the variation in the physiology and genetics of each animal. To fill a gap where there is lack of standardized procedures for quantifying heat stress, a metric called the summer to winter ratio ( $\mathbf{S}: \mathbf{W}$ ratio) was developed by Extension Service of the Ministry of Agriculture and Israel Cattle Breeders Association to evaluate the seasonal effects of heat stress on performance of individual cows (Flamenbaum and Ezra, 2007). The S:W ratio has been used to assess performance variables such as milk production, SCS, and reproductive variables (Flamenbaum and Ezra, 2007). Summer performance variables (numerator) are compared with winter performance variables (denominator) and the closer the ratio is to 1 , the less effect heat stress is having on the variable of interest. The $\mathrm{S}: \mathrm{W}$ ratio has led to improvements in cow cooling in Israel, but this metric has not been utilized extensively. Therefore, the objective of this study was to calculate and compare $\mathrm{S}: \mathrm{W}$ ratios for performance variables among US regions to demonstrate the usefulness of the ratio as a tool to monitor heat stress in US regions.

\section{MATERIALS AND METHODS}

Cow performance data on an individual level, recorded monthly by the DHIA from 2007 to 2016 for all US DHIA herds processing records through Dairy Records Management Systems (DRMS), were obtained and averaged by farm. Holstein herds with 6 to 13 monthly DHIA test days of data per year were included in the data set. Additionally, herds were required to have 2 to 4 test dates per season. Season dates were based on the astronomical definition of the Northern Hemisphere with summer as June 21 to September 21 and winter as December 21 to March 19, as defined by NOAA (2017). December was adjusted to equal the same experimental winter year as the following January based on season and to account for crop season. For example, crops harvested in December 2015 were considered as winter 2016 , as the same crop would be used as feed in the same season as January 2016.

\section{Performance Variables}

Test day performance variables included in the analysis were ECM calculated as ECM $(\mathrm{kg})=(0.327$ $\times$ milk kg $)+(12.95 \times$ fat $\mathrm{kg})+(7.65 \times$ protein $\mathrm{kg})$, mean 150-d milk, milk fat and protein percentage, SCS, conception rate calculated as the number of successful services in each test period divided by the total number of services for that test period, pregnancy rate calculated as the percentage of cows eligible to become pregnant that are reported pregnant within a specific period of time, and heat detection rate (HDR) calculated as the percentage of the possible heats that are detected as \% Heats Observed $=$ [number of services and heats reported in the test period for eligible cows/ (estrous cycle days in test period for eligible cows/21)] $\times 100$. Reproductive variables were excluded for herds that were greater than $25 \%$ bull bred or had less than 5 services. All variables were provided in the data set from DRMS, or appropriate formulas were provided and then calculated in SAS 9.4 (SAS Institute Inc., Cary, NC). Performance variables sorted by test date and herd were then categorized as summer or winter based on test dates.

States were grouped into regions based on climate zone classification (USDA, 2018) as Northeast (humid continental climate with mild summers), Midwest (humid continental climate), Northern Plains (cold semi-arid to humid continental climate), Southeast (humid, subtropical climate), and Southern Plains (primarily humid subtropical climate). A total of 105,279 performance records included a total of 16,573 herds [Northeast $(\mathrm{n}=7,955)$, Midwest $(\mathrm{n}=6,555)$, Northern Plains $(\mathrm{n}=305)$, Southeast $(\mathrm{n}=1,370)$, and Southern Plains $(\mathrm{n}=388)$ regions]. The Pacific Northwest $(\mathrm{n}=$ 7 ) and Southwest $(n=23)$ were excluded from the data set attributable to a small sample size in the DRMS database. The numbers of herds per state are shown in Table 1.

\section{Summer to Winter Ratio Calculation}

Herd test day performance variables in summer and winter were used to calculate S:W ratios for each region. To obtain $\mathrm{S}: \mathrm{W}$ ratios per farm, test day performance data were averaged for summer and winter by herd, season, and year. Summer means were divided by winter means for each performance variable, resulting in one $\mathrm{S}: \mathrm{W}$ ratio for each variable by year for each herd and averaged by region in the final model.

\section{Weather Data}

Weather data were retrieved through the Cli-MATE application from the Midwestern Regional Climate Center (Cli-MATE, 2018). Data obtained included hourly temperature and relative humidity from one weather station per state. Each weather station was chosen based on the county with the highest milk cow inventory from the most current census in 2012 (NASS, 2012). If no weather station was available for that 
Table 1. Number of herds per state included in the data set

\begin{tabular}{lrl}
\hline State & $\begin{array}{c}\text { No. of herds } \\
\text { per state }\end{array}$ & Region \\
\hline AL & 23 & Southeast \\
AR & 25 & Southeast \\
CT & 67 & Northeast \\
CO & 1 & Northern Plains \\
DE & 29 & Northeast \\
FL & 59 & Southeast \\
GA & 162 & Southeast \\
IA & 735 & Midwest \\
IL & 396 & Midwest \\
IN & 376 & Midwest \\
KS & 177 & Southern Plains \\
KY & 304 & Southeast \\
LA & 59 & Southeast \\
MA & 64 & Northeast \\
MD & 205 & Northeast \\
ME & 119 & Northeast \\
MI & 769 & Midwest \\
MN & 2,155 & Midwest \\
MO & 318 & Midwest \\
MS & 29 & Southeast \\
MT & 4 & Northern Plains \\
NC & 143 & Southeast \\
ND & 36 & Northern Plains \\
NE & 129 & Northern Plains \\
NH & 62 & Northeast \\
NJ & 61 & Northeast \\
NY & 2,116 & Northeast \\
OH & 759 & Midwest \\
OK & 60 & Southern Plains \\
PA & 363 & Northeast \\
RI & 36 & Northeast \\
SC & 135 & Southeast \\
SD & 129 & Northern Plains \\
TN & 151 & Southeast \\
TX & 401 & Southern Plains \\
VA & 327 & Southeast \\
VT & Northeast \\
WI & Midwest \\
WV & Northeast \\
\hline
\end{tabular}

county, the weather station of the closest county on the map with available data was chosen to closely resemble a similar climate to the county with the highest milk cow inventory. Provided hourly temperature and relative humidity were averaged by day and mean THI per day was calculated. Daily THI means were averaged by region and year for summer and winter. The THI equation used in this study was THI $=\left(1.8 \times \mathrm{T}^{\circ} \mathrm{C}+\right.$ $32)-(0.55-0.0055 \times \mathrm{RH} \%) \times\left(1.8 \times \mathrm{T}^{\circ} \mathrm{C}-26\right)$, where $\mathrm{T}=$ hourly ambient temperature in ${ }^{\circ} \mathrm{C}$ and $\mathrm{RH}$ $\%=$ hourly relative humidity as a percentage (NRC, 1971).

\section{Statistical Analysis}

All procedures were performed using SAS 9.4 (SAS Institute Inc., Cary, NC). Descriptive statistics were performed for all performance variables. Milk and re- productive performance data were edited by removing variables equal to 0 , indicating likely inaccurate data. Additionally, herd outliers were identified and values less than the 1st percentile or greater than the 99th percentile for the entire data set were removed for performance variables, mean herd size, mean DIM, and $\mathrm{S}: \mathrm{W}$ ratios to avoid errors of data entry and human error attributable to the large data set. Summer to winter ratio outliers were identified and values less than the 5 th percentile or greater than the 95 th percentile were removed. Variables were provided by DRMS and averaged by herd and season. It is important to note that DIM was included as a covariate to account for peak milk production varying from cow to cow. To accurately represent reproduction variables, herds bred to bulls were eliminated from the data set.

Herd test day performance variables in summer and winter were used to calculate $\mathrm{S}: \mathrm{W}$ ratios for each region. The MIXED procedure was used to compare herd average ECM, SCS, fat \%, protein \%, conception rate, pregnancy rate, and HDR S:W ratios as response variables for herds within each US region by year. The effects of year, mean DIM, mean 150-d milk, mean herd size, and number of milkings per day for summer and winter were included as covariates in all models other than ECM and stepwise-backward elimination was performed for each variable to exclude variables that were not contributing significantly to the model $(P>0.3)$. Year was included as a repeated variable and herd as the subject. Significant differences were considered at $P<0.05$. A MIXED model using the LSMEANS statement was used to generate least squares means separations between summer and winter for all performance variables. Additionally, all individual cow binary and reproductive performance variables were summarized as percentages and ratios by herd per year, and treated as a continuous variables.

\section{RESULTS AND DISCUSSION}

Summer and winter mean separations by region for each performance variable make up the final data set and are shown in Table 2. These values were used to calculate $\mathrm{S}: \mathrm{W}$ ratios. Mean \pm standard deviation, DIM, mean herd size, and mean 150-d milk were 187 $\pm 27.08,136 \pm 171.28$, and $33 \pm 5.06 \mathrm{~kg}$ for the data set. Mean, median, maximum, and minimum herd size for the entire data set were 136, 79, 1,486, and 22 dairy cows, respectively. Descriptive data for summer THI averaged over $10 \mathrm{yr}$ showed that numerically, the Northeast, Northern Plains, and Midwest had lower THI compared with the Southeast and Southern Plains regions (Table 3 ). 
Table 2. Descriptive data displaying summer and winter means ( \pm SEM) for each performance variable used to calculate summer to winter ratios for US regions

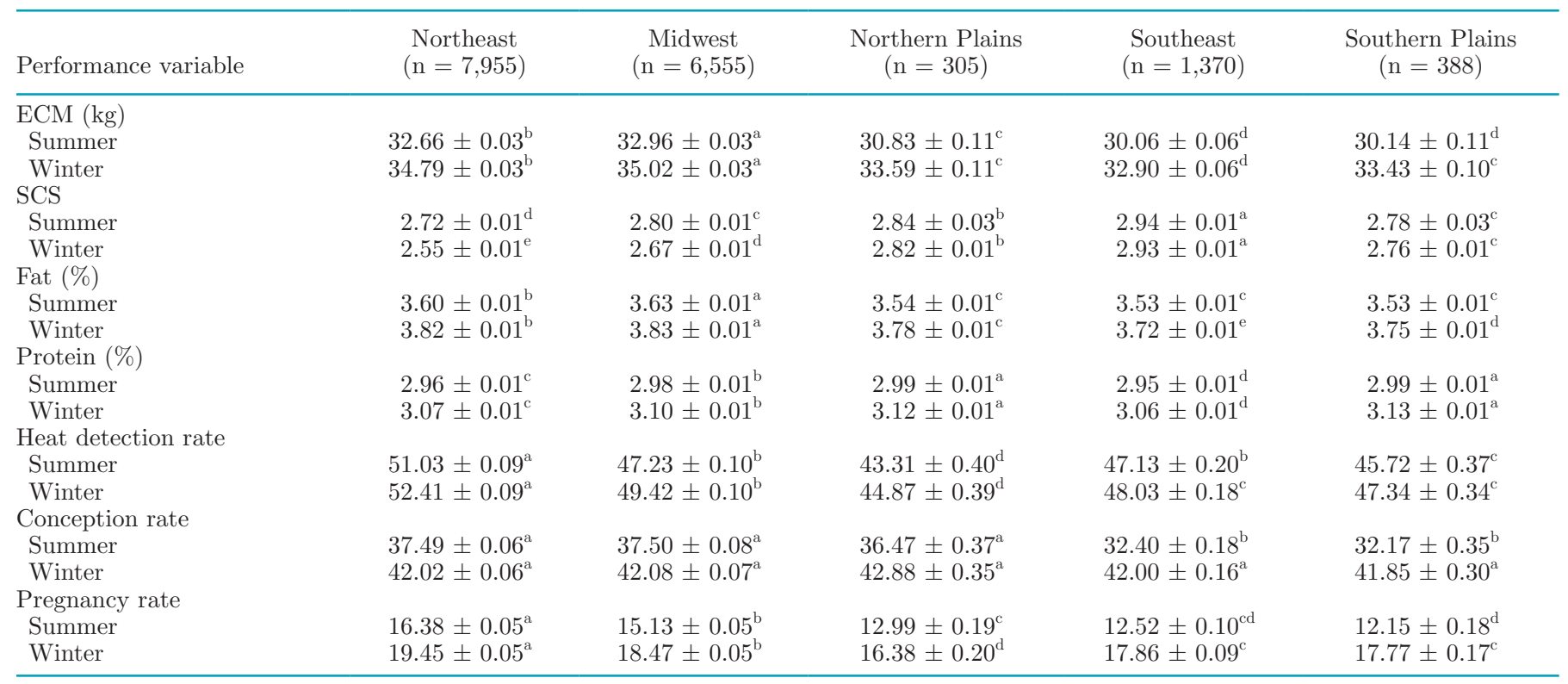

${ }^{\mathrm{a} e}$ Least squares means with different superscripts are different among variable and region across rows $(P<0.05)$.

\section{ECM Production}

The S:W ratios for ECM ranged from 0.87 to 0.94 suggesting that milk production in the winter was greater than in the summer for all regions, as the ratio was less than 1.00. The ECM S:W ratio varied among regions where the Southern Plains region $(0.87)$ had the lowest and the Northeast and Midwest (0.94) had the highest $\mathrm{S}: \mathrm{W}$ ratios $(P<0.001$; Table 4$)$, implying less heat stress experienced by cattle in the regions, more adequate heat abatement management, or a combination of both. Though there is no known threshold for $\mathrm{S}: \mathrm{W}$ ratios corresponding to level of heat stress, the $\mathrm{S}: \mathrm{W}$ ratios for ECM ranging from 0.87 to 0.94 , a difference of 0.07 corresponds to a loss in summer ECM of 3 $\mathrm{kg}$ of milk in the Southern Plains compared with $2 \mathrm{~kg}$ in the Northeast and Midwest (Table 2). Mean THI values in the Northeast and Midwest were 68 compared with 74 in the Southern Plains, indicating a larger drop in summer milk production for regions with a higher THI, corresponding to a higher level of heat stress (Table 3).

Similarly, data reported by St-Pierre et al. (2003) showed greater effects of heat stress in the Southern Plains than the Midwest as daily milk loss per cow was 0.94 and $3.8 \mathrm{~kg}$ and the hours of heat stress per year were 343 and 2,450 for the Midwestern states versus the Southern Plains states, respectively, under conditions of insufficient cooling to animals in confinement.

It is important to note that management practices vary greatly from herd to herd and will cause changes in production; however, consistently lower values in the summer months compared with winter most likely indicate some level of heat stress in all regions and a higher level in others, likely attributable to regional THI. Understanding how to interpret the ECM S:W ratio is key to the usefulness of the ratio. Because ECM is commonly affected by heat stress, utilizing the $\mathrm{S}: \mathrm{W}$ ratio for this variable would be useful as it can quan-

Table 3. Mean, minimum, and maximum $( \pm \mathrm{SD})$ THI averaged over $10 \mathrm{yr}$ by season per region

\begin{tabular}{|c|c|c|c|c|c|}
\hline Year & $\begin{array}{l}\text { Northeast } \\
(\mathrm{n}=7,955)\end{array}$ & $\begin{array}{c}\text { Midwest } \\
(\mathrm{n}=6,555)\end{array}$ & $\begin{array}{l}\text { Northern Plains } \\
\qquad(\mathrm{n}=305)\end{array}$ & $\begin{array}{l}\text { Southeast } \\
(\mathrm{n}=1,370)\end{array}$ & $\begin{array}{l}\text { Southern Plains } \\
\qquad(\mathrm{n}=388)\end{array}$ \\
\hline \multicolumn{6}{|l|}{ Summer } \\
\hline Mean & $67.9 \pm 2.2$ & $67.7 \pm 2.4$ & $64.8 \pm 3.4$ & $73.5 \pm 1.7$ & $73.6 \pm 1.9$ \\
\hline Minimum & $44.0 \pm 5.9$ & $42.0 \pm 5.2$ & $38.7 \pm 6.0$ & $55.9 \pm 6.3$ & $52.9 \pm 6.0$ \\
\hline Maximum & $80.6 \pm 0.3$ & $80.7 \pm 0.2$ & $78.7 \pm 2.6$ & $80.8 \pm 0.0$ & $80.8 \pm 0.0$ \\
\hline \multicolumn{6}{|l|}{ Winter } \\
\hline Mean & $36.9 \pm 3.9$ & $32.6 \pm 5.0$ & $33.6 \pm 2.7$ & $48.4 \pm 4.9$ & $45.0 \pm 5.0$ \\
\hline Minimum & $18.5 \pm 5.3$ & $17.1 \pm 0.9$ & $16.8 \pm 0.1$ & $22.6 \pm 5.7$ & $19.4 \pm 3.5$ \\
\hline Maximum & $63.6 \pm 6.4$ & $58.5 \pm 12.3$ & $62.3 \pm 6.1$ & $71.6 \pm 5.2$ & $72.2 \pm 3.0$ \\
\hline
\end{tabular}


tify changes in production based largely on changes in climate and heat abatement strategies. Although differences were seen among the regions of the United States in this data, the number of observations in the data set was large, which might have affected significance.

\section{Milk Quality}

$S C S$. The S:W ratios for SCS ranged from 1.02 to 1.09, suggesting that SCS was higher in the summer compared with winter for all regions. The SCS S:W ratios were different among regions $(P<0.001)$, with the Northern Plains (1.02) being the lowest and the Southern Plains being the highest (1.09; $P<0.001$; Table 4). The Northern Plains SCS S:W ratio was closest to 1, indicating minimal seasonality in SCS. Somatic cell score for the Southern Plains regions increased from an average of 2.76 in winter to 2.78 in summer, which corresponds to a $1.4 \%$ increase when transformed to SCC (Norman et al., 2000) and a 1.4\% increase for the Northern Plains, indicating that an increase of 1.02 to $1.09 \mathrm{~S}: \mathrm{W}$ ratios between the 2 regions shows minimal change based on summer increases. However, the $\mathrm{S}: \mathrm{W}$ ratios for the Southern Plains region show greater variation according to the 25 th and 75 th percentiles as ratios ranged from 0.97 to 1.18 in the Southern Plains and 0.92 to 1.09 in the Northern Plains (Table 5), indicating that summer SCS reached higher levels in the Southern Plains compared with the Northern Plains. Additionally, averages in all regions were well below the US required limit of 750,000 cells/mL (Norman et al., 2000), and the threshold of 200,000 cells/mL indication of an IMI (Shook, 1982). Surprisingly, the changes in SCS from winter to summer were minimal when compared among US regions.

Further, the Northern Plains region had a mean THI of 65 in the summer, and the Southern Plains region had a mean THI of 74 as a 10-yr average. Based on THI, the SCS S:W ratios were expected as the Northern Plains THI was under the threshold of heat stress of 68 and experience minimal seasonality in SCS. Therefore, exposure to heat stress quantified by THI might influence SCS in varying regions; however, management factors not quantified in this study would also influence performance variables. In comparison, a study by Nasr and El-Tarabany (2017) reported that from low $(<70)$ to high $(>80)$ THI, SCC increased by $36 \%$, but from low $(<70)$ to medium $(70-80)$ THI, SCC increased by $14 \%$. The THI levels in the current study reached low and medium levels of THI for the Northern and Southern Plains regions, respectively.

Milk Fat and Protein \%. The S:W ratio for milk fat $\%$ ranged from 0.94 to 0.96 showing that milk fat $\%$ was lower in summer compared with winter for all 
regions. The Northern Plains had the lowest S:W ratio, whereas the Southern Plains and Southeast had the highest S:W ratios for milk fat $\%(P<0.001$; Table 4$)$. The 25th and 75 th percentile ranges were 0.90 to 0.97 and 0.91 to 0.99 for the Northern Plains and Southern Plains, respectively (Table 5), showing similar variation for the regions. Additionally, the difference in the highest and lowest ratios is 0.02 , suggesting that there is minimal difference between the 2 regions and detected significant differences might be due to the large number of observations in the data set. The $\%$ change in milk fat $\%$ from winter to summer decreased by $5.1 \%$ (from 3.7 to 3.5 ) in the Southeast and $6.4 \%$ (from 3.8 to 3.5 ) in the Northern Plains. This change may not be an alarming amount that would influence management changes. Past research findings are inconsistent regarding the effects of heat stress on milk component changes. For instance, Bernabucci et al. (2015) reported milk fat \% was lower in summer compared with winter, whereas others found no difference between seasons (Hammami et al., 2015). In addition, Nasr and El-Tarabany (2017) reported an inverse relationship between milk components and THI. Fat \% was lower at high THI levels (THI > 80 ) at $3.74 \%$ compared with $3.91 \%$ at low THI levels (THI <70). In the current study, fat $\%$ was also higher at lower THI, apart from the Northern Plains being similar to the 2 southern regions. Fat $\%$ was simi- lar in the Northern Plains, Southeast, and Southern Plains $(3.53,3.54$, and $3.54 \%$, respectively) with $10-\mathrm{yr}$ mean THI values of 65,74 , and 74 for the Northern Plains, Southeast, and Southern Plains. Higher fat \% values were found in the Northeast and Midwest (3.61 and $3.64 \%$, respectively), and THI values were 68 for the 2 regions.

The S:W ratio for milk protein \% ranged from 0.96 to 0.97 for all regions, suggesting that all regions had lower milk protein in the summer. Differences were found among regions $(P<0.001$, Table 4$)$; however, $\mathrm{S}: \mathrm{W}$ ratios for all regions were within 0.01 of each other, suggesting minimal difference among regions. It is likely that the slight differences detected among regions for milk protein \% were influenced by large sample size as the S:W ratios for the 25th and 75 th percentiles only differed between 0.04 to 0.05 for all regions (Table 5). Previous studies have shown inconsistencies in milk components and one study showed a decrease in milk protein yield of $18 \mathrm{~kg}$ and fat yield decrease from $19 \mathrm{~kg}$ from low to high THI (Nasr and El-Tarabany, 2017). Utilizing the S:W ratio for milk fat and protein \% to assess heat stress levels should be taken with caution as data are inconsistent to whether heat stress alters these milk components. Other management changes such as nutrition should be taken into consideration if there are concerns with changes in these variables.

Table 5. Descriptive summer to winter ratio (S:W; quartile 1, median, and quartile 3) distributions for each performance variable for US regions

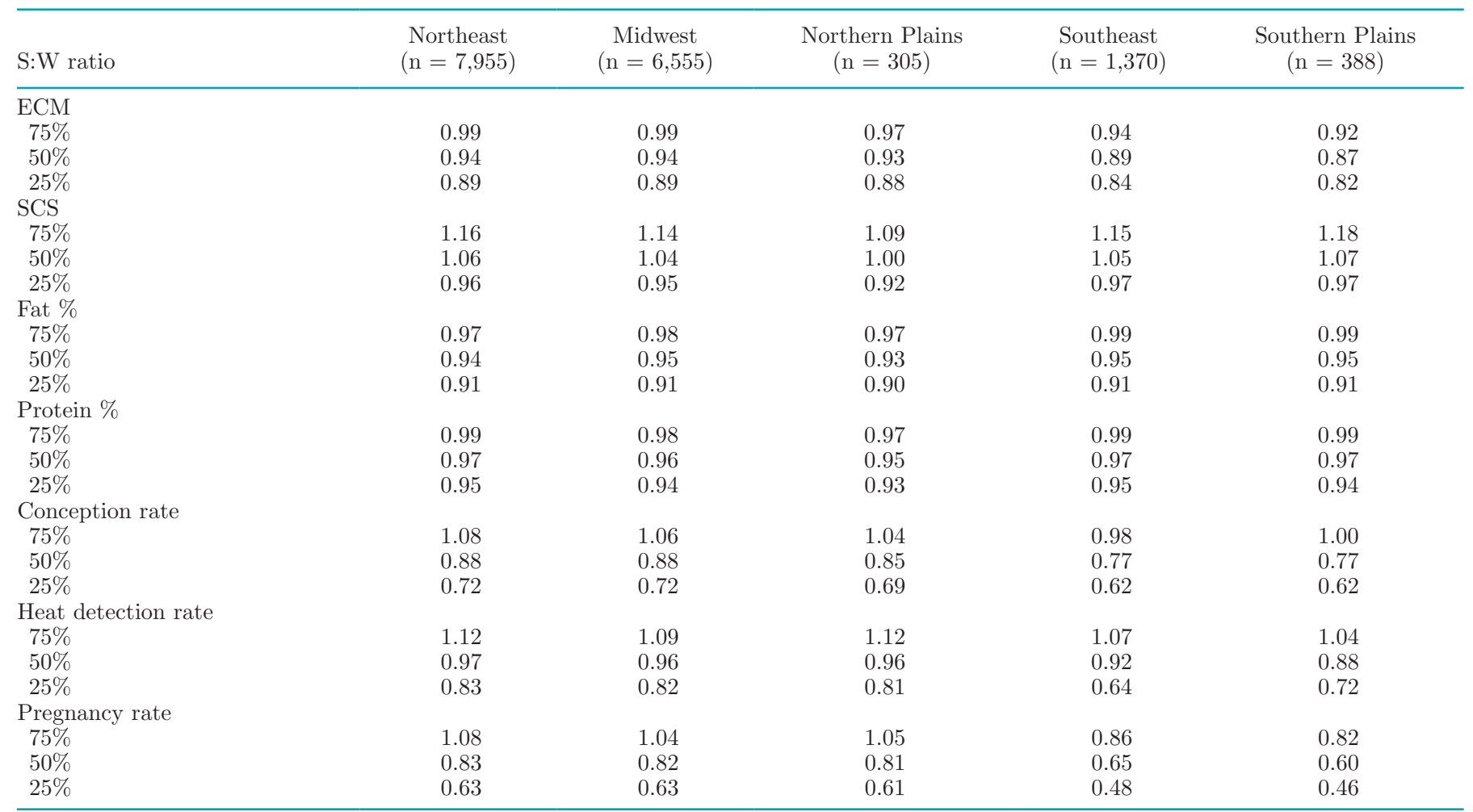




\section{Reproductive Performance}

Heat Detection Rate. The S:W ratios for HDR ranged from 0.89 to 0.99 and were different among regions $(P<0.001$, Table 4$)$. The lowest $\mathrm{S}: \mathrm{W}$ for HDR (0.89) was in the Southern Plains and the highest in the Northeast $(0.99 ; P<0.001$; Table 4$)$. The 25 th and 75 th percentiles ranged from 0.72 to 1.04 and 0.83 to 1.12 for the Southern Plains and Northeast, respectively (Table 5). The 10-yr mean THI for summer was 68 and 74 for the Northeast and Southern Plains, respectively. According to these values, the Southern Plains experienced higher levels of heat stress than the Northeast. These results agree with other studies because heat stress has a known detrimental effect on detecting estrus in dairy cattle (Thatcher and Collier, 1986; Schüller et al., 2016), caused by reductions in activity (Hansen and Arechiga, 1999), direct effects of hyperthermia on the reproductive axis, and the indirect effects associated with reduced DMI (De Rensis and Scaramuzzi, 2003). Up to $80 \%$ of estrus behaviors are not detected because of the effects of heat stress (Thatcher and Collier, 1986). However, it can be typical practice for producers to not breed during the heat of the summer, and if HDR data were not reported during the year, this could affect the results from the data set, and factors other than heat stress might influence the data (Ribeiro et al., 2013).

Conception Rate. The S:W ratios for conception rate ranged from 0.82 in the Southeast and Southern Plains to 0.91 in the Northeast and Midwest. Differences for conception rate $\mathrm{S}: \mathrm{W}$ ratio were present among regions $(P<0.001$; Table 4$)$. The 25 th and 75 th percentile ranges were greater in the southern regions compared with the northern regions, with lower values overall (Table 5). The conception rates in the Northeast and Midwest decreased by $11 \%$ (from 42.02 to 37.49 and 42.08 to 37.50 ) during the summer compared with winter months, and the Southeast and Southern Plains decreased $23 \%$ (from 42.00 to 32.40 and 41.85 to 32.17 ) in the summer. In another study, conception rate S:W ratios were $0.73,0.76$, and 0.38 for cows that were intensively, moderately, and not cooled, in a study in Israel as they declined by nearly $50 \%$ in the summer (Flamenbaum and Galon, 2010). Summer to winter ratios among US regions in the current study were higher and therefore with less seasonality in conception rates than in Israel, but conclusions are difficult to make as we do not know the heat abatement systems used by farms in the data set.

Pregnancy Rate. The S:W ratio for pregnancy rate ranged from 0.68 for the Southern Plains, and 0.89 for the Northeast, with differences among regions $(P<$ 0.001 , Table 4 ). The 25 th and 75 th percentiles ranged from 0.46 to 0.82 and 0.63 to 1.08 for the Southern Plains and Northeast, respectively (Table 5). Pregnancy rates declined by $16 \%$ in the Northeast (19.45 to 16.38 ) and $32 \%$ (17.77 to 12.15) in the Southern Plains from winter to summer, showing the greatest seasonality compared with the rest of the variables, based on the $\mathrm{S}: \mathrm{W}$ ratios. In a study conducted in the subtropical environment of Egypt, under similar THI conditions as the Southern regions in the current study (70 to 75), pregnancy rates in both studies showed a decrease of 40 to $50 \%$ from winter to summer (El-Wishy, 2013). Heat stress is known to influence reproductive variables (El-Wishy, 2013), and data from this study show seasonality in reproductive variables; however, management factors such as accuracy of estrus detection, use of synchronization programs, transition cow management, metabolic health, cow comfort, and lameness also play a role in effects on reproduction (Lucy, 2001; Caraviello et al., 2006).

Cooling cows during the summer is vital, and by using the S:W ratio to monitor how well producers are managing heat stress could lead to increased production and performance in summer months. Its application in the Israeli dairy industry has been successful, as it has led producers to implement intensive cooling systems and, in turn, see improvements in performance (Flamenbaum and Galon, 2010). Applying the S:W ratio in the United States by quantifying performance losses, producers could recognize lost revenue by seeing changes in their $\mathrm{S}: \mathrm{W}$ ratios over time, driving them to improve heat abatement.

\section{Limitations and Recommendations for Future Research}

Although the S:W ratio shows an important role as a key performance indicator, some limitations exist. In this study, it is difficult to compare herds when management varies drastically from farm to farm. For instance, seasonal calving herds have less cows in milk during the summer months, affecting summer milk production and the $\mathrm{S}: \mathrm{W}$ ratio. However, to account for this in the best way possible, DIM was included in models as a covariate. Utilizing the $\mathrm{S}: \mathrm{W}$ ratio to compare one farm to itself over time might also have this issue if they were to alter management practices among years or seasons, such as adjusting the feed ration between seasons. Additionally, housing and herd management practices, such as access to pasture and heat abatement strategies during the study period, could not be accounted for because these data were not available. Therefore, some heat stress effects were likely alleviated, and some more extreme, creating inconsistencies in comparing farms by region. Future research should investigate how nutri- 
tional and managerial factors might affect performance during the summer months compared with the effects of heat stress.

For this study, seasons were defined by the astronomical dates and were the same for each state. Temperatures may vary for the summer season among states. For instance, Florida experiences $50 \%$ of annual hours of heat stress conditions per year (St-Pierre et al., 2003). Therefore, some states experience higher temperatures earlier in the year, possibly before summer begins. Using astronomical dates of summer and winter would therefore exclude periods of heat stress in the spring and carry over effects of reduced performance into the fall. Summer and winter were used in the analysis and the $\mathrm{S}: \mathrm{W}$ ratio assumes that peak performance occurs during the winter, while poorest performance occurs in the summer. This may not always be the case for some farms or regions, and cold stress could also play a role in affecting performance in the winter. Future work could include ratios with various seasons. Regardless of the THI and weather patterns in each region, farms must adapt their practices based on weather consistent with their region. Strategies in the north may not be sufficient for farms in the south because of extended periods of higher temperatures and humidity. The S:W ratios from the data in the current study identify the need to better manage the effects of heat stress in the regions with the lowest $\mathrm{S}: \mathrm{W}$ ratios.

Further development of the formula to become suitable for the use by producers would need to account for variables such as DIM, peak production, and seasonal calving for the ratio to be the most useful on farm. The results from this study are based on data provided by DHIA; however, the S:W ratio could still be used by farms not currently enrolled, and instead as a metric to assess bulk tank variables or variables provided by milking equipment. Limitations exist; however, the $\mathrm{S}: \mathrm{W}$ ratio can still be useful in making management decisions to improve cow comfort and performance.

\section{CONCLUSIONS}

The results from this study identified an effect of summer on performance among regions of the United States, particularly in the Southeast and Southern Plains, as performance variables are not maintained at the same level during the summer as they are in the winter compared with the Midwest, Northern Plains, and Northeast. The results of this study demonstrate the use of the $\mathrm{S}: \mathrm{W}$ ratio in having future potential to benefit producers and consultants as a tool to assess heat stress levels in specific herds or regions, with the goal of encouraging improvement of on-farm heat abatement.

\section{ACKNOWLEDGMENTS}

The Southeast Quality Milk Initiative is supported by the National Institute of Food and Agriculture (Washington, DC), US Department of Agriculture, under award number 2013-68004-20424. Any opinions, findings, conclusions, or recommendations expressed in this publication are those of the author(s) and do not necessarily reflect the view of the US Department of Agriculture. Any opinions, findings, conclusions, or recommendations expressed in this publication are those of the author(s) and do not necessarily reflect the view of the US Department of Agriculture.

\section{REFERENCES}

Berman, A. 2005. Estimates of heat stress relief needs for Holstein dairy cows. J. Anim. Sci. 83:1377-1384. https://doi.org/10.2527/ 2005.8361377x

Bernabucci, U., L. Basiricò, P. Morera, D. Dipasquale, A. Vitali, F. P. Cappelli, and L. Calamari. 2015. Effect of summer season on milk protein fractions in Holstein cows. J. Dairy Sci. 98:1815-1827. https://doi.org/10.3168/jds.2014-8788.

Bohmanova, J., I. Misztal, and J. Cole. 2007. Temperature-humidity indices as indicators of milk production losses due to heat stress. J. Dairy Sci. 90:1947-1956. https://doi.org/10.3168/jds.2006-513.

Caraviello, D. Z., K. A. Weigel, M. Craven, D. Gianola, N. B. Cook, K. V. Nordlund, P. M. Fricke, and M. C. Wiltbank. 2006. Analysis of reproductive performance of lactating cows on large dairy farms using machine learning algorithms. J. Dairy Sci. 89:4703-4722. https://doi.org/10.3168/jds.S0022-0302(06)72521-8.

Cli-MATE. 2018. MRCC Application Tools Environment. Midwestern Regional Climate Center, Champaign, IL. Accessed Jan. 22, 2018. https://mrcc.illinois.edu/CLIMATE/.

De Rensis, F., and R. J. Scaramuzzi. 2003. Heat stress and seasonal effects on reproduction in the dairy cow-A review. Theriogenology 60:1139-1151. https://doi.org/10.1016/s0093-691x(03)00126-2.

Dikmen, S., and P. Hansen. 2009. Is the temperature-humidity index the best indicator of heat stress in lactating dairy cows in a subtropical environment? J. Dairy Sci. 92:109-116. https://doi.org/10 $.3168 /$ jds.2008-1370.

El-Wishy, A. B. 2013. Fertility of Holstein cattle in a subtropical climate of Egypt. J. Appl. Anim. Sci. 3:45-51.

Flamenbaum, I., and E. Ezra. 2007. The "Summer to Winter performance ratio" as a tool for evaluating heat stress relief efficiency of dairy herds. Proc. J. Dairy Sci. 605-606.

Flamenbaum, I., and N. Galon. 2010. Management of heat stress to improve fertility in dairy cows in Israel. J. Reprod. Dev. 56(S):S36S41. https://doi.org/10.1262/jrd.1056S36.

Hammami, H., J. Bormann, N. M'hamdi, H. H. Montaldo, and N. Gengler. 2013. Evaluation of heat stress effects on production traits and somatic cell score of Holsteins in a temperate environment. J Dairy Sci. 96:1844-1855. https://doi.org/10.3168/jds.2012-5947.

Hammami, H., J. Vandenplas, M.-L. Vanrobays, B. Rekik, C. Bastin, and N. Gengler. 2015. Genetic analysis of heat stress effects on yield traits, udder health, and fatty acids of Walloon Holstein cows. J. Dairy Sci. 98:4956-4968. https://doi.org/10.3168/jds.2014 -9148 .

Hansen, P. J., and C. Arechiga. 1999. Strategies for managing reproduction in the heat-stressed dairy cow. J. Anim. Sci. 77(Suppl. 2):36-50. https://doi.org/10.2527/1997.77suppl_236x.

Lucy, M. C. 2001. Reproductive loss in high-producing dairy cattle: Where will it end? J. Dairy Sci. 84:1277-1293. https://doi.org/10 $.3168 /$ jds.S0022-0302(01)70158-0.

Nasr, M. A., and M. S. El-Tarabany. 2017. Impact of three THI levels on somatic cell count, milk yield and composition of multiparous 
Holstein cows in a subtropical region. J. Therm. Biol. 64:73-77. https://doi.org/10.1016/j.jtherbio.2017.01.004.

NASS. 2012. Quick Stats Milk Cow Inventory. United States Department of Agriculture. Accessed Nov. 20, 2018. https://quickstats .nass.usda.gov/.

NOAA. 2017. Meteorological Versus Astronomical Seasons. Accessed Aug. 20, 2018. www.ncei.noaa.gov.

Norman, H. D., R. H. Miller, J. R. Wright, and G. R. Wiggans. 2000. Herd and state means for somatic cell count from dairy herd improvement. J. Dairy Sci. 83:2782-2788. https://doi.org/10.3168/ jds.S0022-0302(00)75175-7.

NRC. 1971. A Guide to Environmental Research on Animals. National Academies of Sciences, Washington, DC.

Polsky, L., and M. A. von Keyserlingk. 2017. Invited review: Effects of heat stress on dairy cattle welfare. J. Dairy Sci. 100:8645-8657. https://doi.org/10.3168/jds.2017-12651.

Ribeiro, E. S., F. S. Lima, L. F. Greco, R. S. Bisinotto, A. P. A. Monteiro, M. Favoreto, H. Ayres, R. S. Marsola, N. Martinex, W. W. Thatcher, and J. E. P. Santos. 2013. Prevalence of periparturient diseases and impacts on fertility of seasonally calving grazing dairy cows supplemented with concentrates. J. Dairy Sci. 96:5682-5697. https://doi.org/10.3168/jds.2012-6335.

Schüller, L.-K., O. Burfeind, and W. Heuwieser. 2016. Effect of shortand long-term heat stress on the conception risk of dairy cows under natural service and artificial insemination breeding programs. Delayed effect of heat stress on steroid production in mediumsized and preovulatory bovine follicles. J. Dairy Sci. 99:2996-3002. https://doi.org/10.3168/jds.2015-10080.

Shook, G. E. 1982. Approaches to summarizing somatic cell counts which improve interpretability. Page 150 in Proc. 21st Natl. Mastitis Counc. Natl. Mastitis Counc., Arlington, VA.

St-Pierre, N., B. Cobanov, and G. Schnitkey. 2003. Economic losses from heat stress by US livestock industries. J. Dairy Sci. 86:E52E77. https://doi.org/10.3168/jds.S0022-0302(03)74040-5.
Thatcher, W., and R. Collier. 1986. Effects of climate on bovine reproduction. Current Therapy in Theriogenology 2:301-309.

USDA. 2018. Climate Hubs. Accessed Aug. 20, 2018. https://www .climatehubs.usda.gov/.

West, J. W. 2003. Effects of heat-stress on production in dairy cattle. J. Dairy Sci. 86:2131-2144. https://doi.org/10.3168/jds.S0022 -0302(03)73803-X.

Zimbelman, R. B., R. P. Rhoads, M. L. Rhoads, G. C. Duff, L. H. Baumgard, and R. J. Collier. 2009. A re-evaluation of the impact of temperature humidity index (THI) and black globe humidity index (BGHI) on milk production in high producing dairy cows. Pages 158-169 in Proceedings of the Southwest Nutrition Conference. R. J. Collier, ed. Accessed Oct. 2, 2019. http://wdmc .org/2011/A\%20Re-Evaluation\%20of\%20the\%20Impact\%20of\%20 Temperature $\% 20$ Humidity $\% 20$ Index $\% 20$ (THI) \%20and $\% 20$ Black \%20Globe\%20Humidity\%20Index\%20(BGHI)\%20on\%20Milk\%20 Production \%20in\%20High\%20Producing\%20Dairy\%20Cows\%20 pg\%20113-126.pdf.

\section{ORCIDS}

D. T. Nolan $\odot$ https://orcid.org/0000-0001-7745-0454

P. D. Krawczel ๑ https://orcid.org/0000-0002-9867-2280

C. S. Petersson-Wolfe — https://orcid.org/0000-0002-2766-1306

G. M. Pighetti $\odot$ https://orcid.org/0000-0003-0947-2381

A. E. Stone $(1)$ https://orcid.org/0000-0001-5687-3394

S. H. Ward () https://orcid.org/0000-0002-8431-364X

J. M. Bewley ๑ https://orcid.org/0000-0002-7347-2741

Joao H. C. Costa @ https://orcid.org/0000-0001-9311-4741 